\title{
Understanding of life style disorders and their prevention in Unani medicine
}

\begin{abstract}
Non communicable diseases (NCDs) are the group of diseases which remain restricted to the affected person only. Various diseases like Atherosclerosis, Myocardial infarction, COPDs, Diabetes, Obesity etc are included in NCDs. According to Unani system of medicine replenishment to the body is provided by Quwwat Ghädhiya (Nutritive faculty) and its four assisting Quwā i.e Quwwat Jädhiba (Absorptive faculty), Quwwat Māsika (Retentive faculty), Quwwat Hādima (Digestive faculty) and Quwwat Däfi'a (Expulsive faculty). These Quwā are served by Kayfiyāt Arba 'a (Four qualities) i.e Harārat, Burūdat, Rutūbat and Yubūsat. So any deviation in these Kayfiyāt Arba 'a may lead to NCDs. NCDs are endogenous in origin and their causes may primarily or secondarily be related to the diet. The diet is never absolute. During Hadm 'Udww , Quwwat Ghädhiya takes only required nutritive substances from it and remaining parts are excreted from the body in the form of Fuzlat (waste materials). The nature and duration of NCDs depends upon the nature of these Fuzlat. When Fuzlat accumulate in any organ, swelling may result e.g Waram al-Kabid (Hepatic swelling). Tabi 'at may divert the fuzlat to other organs of the body to decrease the Imtila (Congestion) and protects the body from harmful effects. Various skin disorders like Taqashshur al-Jild (Psoriasis), Mental disorders like Sahr (Insomnia), Mālankhūliya (Melancholia) etc are because of Fuzlat and are included in NCDs.
\end{abstract}

Volume 10 Issue 4 - 202I

\author{
Sayed Tauleha,' Mohammad Zulkifle, ${ }^{2}$ Waqar \\ Ahmed,' Sana Kausar' \\ IPG Scholar, Department of Kulliyate Tib, National Institute of \\ Unani Medicine, Bangalore \\ 2HOD, Department of Kulliyate Tib, National Institute of Unani \\ Medicine, Bangalore
}

Correspondence: Sayed Tauleha, PG Scholar, National Institute of Unani Medicine, Kottigeplaya, Magadi Main Road, Bengaluru, India 56009I,Tel 076663494I8, ORCID 0000-0002-7357-48IX, Email taulehabukhari20@gmail.com

Received: May 23, 202I | Published: July 16, 202 |

Keywords: haḍm 'uḍwi, kayfiyāt arba' a, Ncds, prevention, quwā

\section{Introduction}

Non communicable diseases (NCDs) are the group of diseases which remain restricted to the affected person only and does not transmit to other people either directly or indirectly. ${ }^{1}$ All categories of diseases except infectious diseases come under the heading of NCDs e.g. Metabolic diseases, Endocrinal diseases, Neoplastic diseases and Nutritional diseases. ${ }^{2}$ In terms of social medicine, the disease considered as NCD when the number of cases are significant and the cost of treatment is also considerable. Some of the important NCDs are Cardiovascular diseases- (Coronary artery disease), Hypertension, Obesity, Cancer, Diabetes mellitus, Blindness, Dyslipidaemia, COPD, Osteoporosis and Goitre., ${ }^{2,3}$ Apart from these, there are number of diseases which are limited to the affected person but their incidence is quite low.

Now a days, increasing incidence of these diseases and their complications have greatly affected the world and tragedy is that there is no satisfactory treatment for these diseases and their complications. These patients impose a great economic burden on society and the country. ${ }^{4}$ Because of this, the government of every country is focused on preventing these diseases and taking all the possible steps towards this. Experts of every medical system are also attracted to provide satisfactory solution for containment of these diseases. The unani medicine also has a role to play in this matter. First of all, it is very important to understand the pathological unani perspective of these diseases.

\section{Discussion}

Disturbances in the Asbāb Sitta Darūriyya Wa Ghair Darūriyya (Six essential factors and modifiable factors), mentioned in the unani system of medicine, are the definite cause for NCDs. ${ }^{5,6}$ Because these are the efficient causes and are responsible for maintaining the proper temperament of the body. ${ }^{7,8}$ Therefore, any disturbance in them causes altered temperament, if this is not corrected, the remaining Umūr Tabi 'iyya (Factors of the existence) are also affected as well..$^{9,10}$ In fact, life style means how a person is practicing Asbāb Sitta Darüriyya Wa Ghair Darūriyya (Six essential factors and modifiable factors) in his or her daily life. Thus, all the life style disorders are associated with these causes. ${ }^{5}$ Since Asbāb Sitta Darüriyya are efficient cause for the body and temperament, therefore they affect the body as well as Mizāj (Constitution or Temperament) and Quwa (Faculties). ${ }^{10}$

Any disturbance in these causes mainly affects the Harārat Ghariziyya (Innate heat), which is a common tool for the Tabí'at (Medicatrix naturae) and Quwā (Faculties). ${ }^{8,9}$ When Mizāj (Constitution or Temperament) changes it directly affects the Quwa ${ }^{11}$ Thus, $Q u w \bar{a}$ do not perform theirs functions properly. First of all, Quwwat Tabì'iyya (Natural faculty) is affected which secondarily affects the remaining two Quwā i.e. Quwwat Haywāniyya (Vital faculty) and Quwwat Nafsāniyya (Mental faculty). ${ }^{10}$ Therefore, diseases produced due to disturbance in Asbāb Sitta Darūriyya are related with the alteration in $A f^{\prime} \bar{a} l$ Tabì'iyya (Natural functions), $A f^{\prime} \bar{a} l$ Haywāniyya (Vital functions) and $A f^{\prime} \bar{a} l$ Nafsāniyya (Mental or Psychic functions). These altered functions depend on age, sex, Mizajj, susceptibility, strength of cause and duration of contact. All are not affected equally.

The two basic functions of Quwwat Tabī'iyya (Natural faculty) are nutrition and reproduction. ${ }^{11,12}$ It is not necessary that both the functions are equally affected by the impairment of Quwwat Tabi'iyya. The disturbance in Fi'l-i- taghdhiya (Function of Nourishment) appears first which later on affects the functions of Quwwat Nafsāniyya and Haywäniyya. ${ }^{10}$ In terms of susceptibility, sometimes diseases of nervous system and vital organs appear first. Whereas the defect in the Fi'l-i-taghdhiya (Function of Nourishment) does not appear or is not noticeable. 
Ghidha (Diet)provide materials that are used by Quwwat ghädhiya (Nutritive faculty) to perform the Fi'l-i-Taghdhiya-o-Tanmiya (Function of Nourishment and growth). ${ }^{9,13,14}$ Ghidha affects the body by two things i.e. by its Kamiyat (Quantity) and Kaifyat (Quality). ${ }^{8,10,14}$ The balance of Akhlāt (Humours) in body specially depends on the Ghidha (Diet). Because Akhlät are produced from Ghidha during Hadm kabidi (Hepatic digestion). ${ }^{11,15}$ The Harārat (Heat) of liver acts on ghidha, different components of ghidha accept the act of heat differently. ${ }^{10,15}$ The Harārat Mu 'tadila (Moderate heat) of liver when acts on Hārr Raț (Hot and moist) components of ghidha then it forms Khilt Dam (Blood). ${ }^{9,10,11,15}$ Similarly, Hārr Yābis (Hot and dry), Bārid Raț (Cold and moist), Bārid Yäbis (Cold and dry) components form Khilt Safrā' '(Yellow bile), Khilt Balgham (Phlegm) and Khilt Sawdā' (black bile) respectively. ${ }^{9,11,13,15}$ Increase in this Harärat causes the production of more Khilt Safra ' while its decrease is responsible for the production of Khilt Balgham. ${ }^{15}$ In this way the proportion of Akhlāt (Humours) deteriorates. ${ }^{10}$

During the process of Hadm (Digestion) undigestible components accumulate in the body in the form of wastes. The quantity of these Fuzlat (Wastes) depends upon the Kayfiyat (Quality) and Kamiyat (Quantity) of ghidha. ${ }^{8}$ Bad quality of food and excess intake of food increase the production of Fuzlat. If their volume exceeds the capacity limit of Quwwat Dāfi'a (Expulsive faculty), they begin to accumulate in the body. ${ }^{11}$ The portion of food that is not digested is also in the same category. Anyhow part of diet beyond upper limit of Quwwat Hädima (Digestive faculty) and wastes over the capacity of Quwwat Dāfi'a (Expulsive faculty), suppress the Harārat Gharizziyya (Innate heat) and because of their quantity causes Burüdat (Cold). ${ }^{10,14}$ After a duration, the Mizāj of the body becomes Bārid and gradually the symptoms of dominance of Burūdat (Cold) on the body begin to appear. ${ }^{9,12,16}$ Mãddi Amrā d (Materialistic diseases) also begin to appear due to the Fuzlat (Wastes) of the body. ${ }^{8}$ If these materials get infected then Ufooni Amrā (Infective diseases) appear. ${ }^{8}$

Similarly, A'itadal (Moderation) in other Asbāb Sitta Darūriyya (Six essential factors) like Harakat-o-Sukūn Badnī (Bodily movement and Repose), Harakat-o-Sukūn Nafsān̄̄ (Psychic movement and Repose), Nawm-o-Yaqza (Sleep and Wakefulness) are also responsible for maintenance of Harārat Gharīziyya (Innate heat). ${ }^{5,7,8,11}$ These Harkāt (Movements) cause Harārat (Heat) to rise which not only causes dissolution of Mawād (Matter) but also, are responsible for excellent performance of Quwāa..$^{5,7,9,17,18}$ Excess of Harakat Nafsāni \& Yaqza or increase in Nawm and decrease in Harakat Badni increase Burūdat in Mizāj and decrease in dissolution which lead to the accumulation of $M a w \bar{a} d$, which becomes an additional factor to reduce the Harārat (Heat). ${ }^{7,15}$ Reduced dissolution and elimination cause retention of Mawād (Matter) and consequently Harārat declines. ${ }^{8,9,17}$ In this way, Burüdat (Cold) becomes dominant due to imbalance in Asbāb Sitta Darūriyya. ${ }^{9,12,16}$ If this Burūdat persists for a long, its effects begin to appear. ${ }^{8}$ These effects depend on the body's Mizāji (Temperamental), Saakhti (Structural), Jinsi (Gender), Nizāmi (Systemic) susceptibilities. ${ }^{10}$ Their prediction is not easy but overview of effects is possible.

Burūdat is Kayfiyāt Fa' 'ila (Active property) therefore, it acts upon the Fuzlat (waste) and Ruțūbat. ${ }^{10}$ If Harārat (Heat) acts on Rutūubat Șălih (Healthy moisture) then it converts them into Lahmiyāt (Proteins) but if Burūdat (Cold) acts then they are converted into Shahmiyāt (Fat). The fat accumulates in the body when Ruțūbat (Moisture)and Burüdat exist together., ${ }^{9,12}$ Shaḥm (fat) itself is a cause of Burūdat and its maintenance. In this way the amount of fat increases. Initially Tabī'at (Medicatrix naturae) starts to deposit this fat on Bārid $A^{\prime} d \bar{a}^{\prime}$
(Cold organs) and then as the others organs get affected by Burūdat, the fat accumulates on them., ${ }^{9,12,16}$ Tabi 'at (Medicatrix naturae) send the excess amount of fat to skin. This causes the accumulation of fat to begin below the skin, and it grows continuously which is the beginning of becoming fatty.

Excessive amount of fat makes lumen of the vessels narrow. At the same time, the effects of Burüdat cause them to constrict which in turn reduces the supply of $R \bar{u} h$ (Pneuma) to certain organs. ${ }^{14}$ Because of this Burūdat, Rūh (Pneuma) also becomes Ghaliz (Viscous), so the $R \bar{u} h$ (Pneuma) does not pass easily through narrow paths. Organs like brain and heart are affected most by decreased supply of R $\bar{u} h$ (Pneuma). The functions of heart are related with Harärat. ${ }^{14}$ When Burūdat affects the heart, it can cause death immediately. If brain is involved then diseases like Falij (Paralysis), Laqwa (Facial palsy), Khidar (Numbness) may occur.

Because blood is the carrier of both Rūh (Pneuma) and Harārat Gharizziyya (Innate heat) and supplies Harārat (Heat) and Rūh Haywāni (Vital pneuma) to the whole body. ${ }^{14,19}$ So, when the Burūdat and Rutübat in the body becomes predominant, then vessels get constricted and if there is too much fat in the body, the vessels become narrower/ compressed due to excess fat. ${ }^{10}$ This process not only affects the blood vessels but also nerves, which makes the supply of Rüh Nafsāni (Psychic pneuma) difficult or block it. So, the heart pumps blood into the vessels with a greater force to maintain the supply of Rūh (Pneuma) and blood. The Quwwat Haywāniyya Fā ila (Active vital faculty) of heart increases, which in turn increases the process of contraction and relaxation of arteries and this condition is known as Daght al-Dam Qawi (Hypertension). ${ }^{9}$

Quwwat Tabí'iyya (Natural faculty) is affected more by Burūdat (Cold) which weakens the process of digestion and assimilation. Since the Hadm ' $U d w \bar{l}$ (Organic Digestion) also declines..$^{12}$ Therefore, the $A^{\prime} d \bar{a}^{\prime}$ (organs) are unable to use the ghidha and this ghidha is accumulated in the spaces and vessels of the organs. ${ }^{20}$ Now this diet is also included in the Fuzlat (Wastes) because Tabi 'at (Medicatrix naturae) is not acting upon it. So, the Quwwat Dāfi'a (Expulsive faculty) tries to expel it. ${ }^{12,15}$ Because of Burüdat (Cold) of liver the Kaymūs (Chyme) does not go through further processing therefore, Akhlāt Khām (Immature humours) increases in the body. ${ }^{10,15}$

If there is Lazoojat (Adhesiveness) they become attached to the walls of cavities and vessels. Narrowing them it decreases the supply of blood and Rüh Haywān̄ (Vital pneuma), causing a variety of complications/ disorders. ${ }^{10}$ This is the beginning of cardiovascular and neurovascular diseases. Circulating and delivered unprocessed Kaymüs (Chyme) cannot be digested, which leads to compositional deterioration of humours and the proportion of undigested and unprocessed components in blood increases. ${ }^{10}$ Now a days same is called as dyslipidaemia, hyperglycaemia, hypercholesterolaemia and hypertriglyceridemia. $^{21}$

\section{Conclusion}

From the above discussion it is clear that when $S \bar{u}-{ }^{\prime} i-M i z a \bar{j} j$ Bârid (Impaired Cold Temperament or Constitution) occurs. ${ }^{8}$ It affects various organs of the body and body becomes full of Mawād (Matters). Tabī'at (Medicatrix naturae)tries to expel these substances. When joints accept these Mawād (Matter), joint pain occurs. When they accumulate in a particular organ, different type of Awrām (Swellings) occur. ${ }^{5,10}$ Becoming infected these Mawād (Matters) form abscesses. ${ }^{10}$ When they turn to the uterus, they cause menstrual disorders. The uterus is unable to nurture the zygote consequently zygote doesn't retain and infertility result. ${ }^{5,14}$ 
In this way the Burūdat affects the whole body. All the organs are more or less affected. The Quwa become weak and Harārat Ghariziyya (Innate heat) drops. ${ }^{10}$ The supply of Rūh (Pneuma) becomes difficult. Affected one cannot reach expected age and premature death occurs. . $^{12,14,18}$

After understanding the pathogenesis, the prevention of these diseases can be discussed. Prevention from NCDs especially metabolic diseases depends on the following; ${ }^{5,10}$

a. Keeping the Harārat Ghariziyya (Innate heat) at optimum level and trying to increase it.

b. Keep the body free from Fuzlat (Waste materials).

c. Moderate practice of Tadabeer Muhallilah (Dissoluting measures) in moderation.

d. Monitoring of humours and wastes production.

Body movements are important to keep innate heat aroused and help to increase it. ${ }^{10}$ Moderate mental activity and sleep also play an important role. ${ }^{10}$ Apart from these, if other causes such as Riyädat (Exercise), Hammām (Turkish Bath), Dalak (Massage), Sun bath etc. ${ }^{14,22}$ taken in moderation the body does not lose Harārat (Heat) and remains protected from the effects and complications of Burūdat (Cold). ${ }^{9,12,16}$ These measures also facilitate the process of dissolution. Due to this dissolution, substances are released from the body in the form of vapours and sweat. ${ }^{8,16}$ The heat makes the substances Lateef (Light weight), ${ }^{12}$ which makes the action of Tabī'at (Medicatrix naturae) easy on them and repulsive faculty, expel them through the easiest way. ${ }^{5,9,12}$

Quwwat Tabìiyya (Natural faculty) becomes strong due to preserved heat and dissolution of wastes and it acts well on food which reduces the production of wastes and food is well digested and assimilated, the rest of the faculties remain strong. ${ }^{8}$ By which Tabí' $a t$ (Medicatrix naturae) performs all its functions well and health is maintained.

Since wastes are produced from food hence maintenance of health and treatment of disease depend on modulation in diet. In terms of Kamiyat (Quantity) the diet should be proportional to the dissolution. ${ }^{10,14,23}$ If there are Fuzlat (Wastes) in the body, then food that produce these Fuzlat should be avoided. ${ }^{10,20}$ Unani physicians have suggested dieting to protect health and prevent the production of wastes which is very effective method. In short, in case of predominance of certain humour, avoiding the humour producing food and intake of quality moderating food restores the healthy proportions of humours and thereby health. ${ }^{10}$

Measures to protect against NCDs such as Tadabir Muhallila (Dissoluting measures), taqleel tadabir (Dieting), heat inducing measures are to be taken in moderation. Moderation in practice of Asbāb Sitta Darūriyya Wa Ghair Darūriyya Ghair madhada (Six essential factors and modifiable factors) is a guarantee of protection from NCDs and also from their progress. ${ }^{5,6,9,22}$

\section{Acknowledgments}

None.

\section{Funding}

This research did not receive any specific grant from funding agencies in the public, commercial or non-for-profit sectors.

\section{Conflicts of interest}

None.

\section{References}

1. AU Gamage, PL Jayawardana. Knowledge of Non-Communicable Diseases and Practices Related to Healthy Lifestyles Among Adolescents, In State Schools of a Selected Educational Division in Sri Lanka. BMC Public Health. 2017;18(1):64.

2. K Park. Park's Textbook of Preventive and Social Medicine. $22^{\text {nd }}$ edition. Jabalpur (M.P.): M/s Banarsidas Bhanot Publishers. 2013.

3. Nethan S, Sinha D, Mehrotra R. Non-Communicable Disease Risk Factors and their Trends in India. Asian Pacific Journal of Cancer Prevention. 2017;18(7):2005-2010. DOI: 10.22034/APJCP.2017.18.7.2005

4. Habib SH. Burden of Non-Communicable Diseases: Global overview. Diabetes \& Metabolic Syndrome: Clinical Research \& Reviews. 2010;4(1):41-47.

5. Baghdadi IH. Kitabul Mukhtarat-Fil-Tibb (Urdu Translation by CCRUM). Vol 1. $1^{\text {st }}$ Ed. New Delhi: Model Offset works. 2005.

6. Firdaus S, Ali F, Sultana N, et al. An overview on Six Essential PreRequisites or Asbab e Sitta Zarooriya In Prevention of Diseases and its Correlation with Tabiat. American Journal of Pharmtech Research. 2016;6(1):25-39.

7. Jalinus. Kitab-Fi-Firaq Al-Tib (Edited and Translated by Zillur Rahman H.S.). Aligarh: Ibn Sina Academy. 2008.

8. Nafis Allama. Kulliyat-e- Nafisi (Tarjuma wa Sharah by Hkm Kabiruddin). New Delhi: Idara Kitabul Shifa. 1954.

9. Majoosi AIA. Kamilus Sanaa. New Delhi: Idara Kitabul Shifa. 2010.

10. Ibn Rushd AW. Kitabul Kulliyat. Lahore: Maktaba Daniyal. 2017.

11. Masihi AS. Kitab-ul-Miah (Urdu Translation by CCRUM). New Delhi: CCRUM. 2008.

12. Ibn-Sina SR. Al-Qanoon (Urdu translation by Ghulam Husnain Kantoori). New Delhi: Idara Kitabul Shifa; YNM.

13. Jalinoos. Kitab fil Anasir (Urdu Translation by Rehman SZ). Aligarh: International Printing Press. 2008.

14. Tabri R. Firdous-ul-Hikmat (Urdu Translation by Sambhali MAS). New Delhi. Idara Kitabul shifa. 2017.

15. Jurjani IA. Zakhira Khawarzam Shahi (Urdu translation by Hadi Husain Khan). New Delhi: Idara Kitabul Shifa. 2010.

16. Ibn Sina SR. Kulliyat-e-Qanoon. (Urdu translation by Kabiruddin HM) New Delhi: Aijaz Publication House. 2006.

17. Tabri A AM. Moalajat Buqratiyah (Urdu Translation). Vol.3. New Delhi: CCRUM. YNM.

18. Harwi MBY. Ain A1-Hayat (Urdu Translation by Rahman HSZ). Aligarh: Ibn Sina Academy. 2008.

19. Kabiruddin M. Ifada-e-Kabir. New Delhi: Idara Kitabul Shifa. 2019

20. Raazi AMIZ. Kitabul Mansoori. New Delhi: CCRUM. 1991.

21. Gupta G, Rao RS, Misra A, et al. Recent Trends in Epidemiology of Dyslipidemias in India. Indian Heart Journal. 2017;69(3):382-392.

22. Ibn Zohar AMA. Kitabu Al-Taiseer. (Urdu Translation). New Delhi: CCRUM. 1986.

23. Razi AMIZ. Kitabul-Murshid (Urdu translation by Nadvi RI). New Delhi: Taraqqi Urdu Bureau. 2000. 